\title{
THE ENGLISH TEACHERS' COMPETENCIES IN ENGLISH FOREIGN LANGUAGE LEARNING AT MA MADANI ALAUDDIN PAO-PAO GOWA, SOUTH SULAWESI
}

\author{
Nurul Azhar \\ Mardiana \\ English Education Department \\ Nurulazhar35@gmail.com
}

\begin{abstract}
The objective of this research was to find out the of competencies of teachers in MA Madani Alauddin, Pao-Pao, which is only split into pedagogical and professional competence. The design of this research was qualitative descriptive. This research had two teachers as the subject. The data were collected through observation and interview. The researcher conducted a straight observation in the teaching and learning process of both teachers. In the classroom, the researcher matched what the teacher did with what observation list contained. Meanwhile, on this point, there are two types of interview, structured interview and unstructured interview. Structured interview was given to ask what teachers used to do in the classroom, in short, what they comprehend about professional and pedagogical competence. Unstructured interview was conducted by setting some students into the researcher talk in daily. Thus, it could fix about what the teacher did through the observation and their information with the students opinion. Furthermore, first, the pedagogical competence through the data gained between both teachers was in the deeply different level. One teacher,female, was not a favorite teacher due to her teaching style. It was gained through some interviews with students which was reverse to what the teacher displayed. While other teacher, male, was the favorite teacher due to the contrary to what the previous teacher did. Overall, it was found that commonly students demanded the teacher extremely focused on what the students need like games which used to be forgotten by the teacher. As a whole they had been claimed as a professional teacher because they significantly concerned with things such as the mastery of material, the use of technology, and the professional continuity.
\end{abstract}

Keywords: English Foreign Language Learning(EFL), Teacher Competencies, English Teachers.

\section{INTRODUCTION}

eachers have strategically important roles to raise the nation characters and to develop students' potential in Indonesian education frame. Meanwhile, the education now is pushed to meet the society need and to answer the local and global

defiance, for instance; the fast rate of informational society, science and technology, and socio-culture.

The increase of teacher profesionalism is an effort to take the unqualifed teachers to be profesional teachers. On this side, the teahers are the whole central figure when it comes 
to education talk because they are always driven into education elements. Besides, they are the key-term to students' succeed in the learning process and the main actor for high quality education. Therefore, it will contribute nothing if the attempt to intensify the quality is conducted but never be supported with the professional teachers whatever the affairs are.

In the same time, Indonesia faced another problem of the low teachers' competitiveness which indicates that Indonesian education is still unable to bring about high quality human resource. In other words, the kind of preparations must begin and be ended by teachers, however the professionalism aid is just an aid. Thus, the teachers themselves must participate more actively.

According to Mulyasa (2012), this has been conducted many times but its materialization is faced to constraint either in Ministry of National Education or in teachers maker institution,for example,no serious attempt to handle education trouble, unanccountablity between quality program and quality of participants by education department directorate. Consequently, It makes some teachers confused in their teaching system moreover, after currilulum changing, teachers in some schools still do not comprehend it.

A variety of trainings has been excuted by the governrment in order to creating high quality teachers such as certification and teacher professional advancing(PPG). However, the researcher finds the opposite side in the field. Teachers seem to only pursuit the training tip,for example, when the researcher did observation in his teaching practice in one of senior high schools in Makassar, it was compeletly different from what was expected because at that time teacher only did Grammar translation method (GTM) meanwhile the content of the lesson was about expression that could be put into Total physical response method. In other words, the learning process in twice observations was simply monotonous. Furthermore, some students told their boredom to the researcher. Another example was of small talk with researher's companion that his teacher sometimes only made a group discussion then left the students, and after the teacher explained the content, the students were asked to do the task while the teacher went out.

Next, researcher also exprerienced another case of teacher unmastery of English when he did social internship several months ago. The English teacher severely focused on writing the material on the blackboard or reading the book and left only few minutes. It was because there were not enough English teachers, yet many classes should be handled so the English lesson was just taken to who had a bit knowledge of English with no teaching style and ability to put things around into lesson media. Consequently, the students were not enthusiastic with the lesson because of uncompetent teacher and English was not clear which could be extrinsic motivation for the students if it was.

On top of that, it needs a twice-attention to competencie itself due to its some similiarities as pedagogical competence. Therefore, these two competencies must be acquired 
by teachers in order to accomplish educational goal. Eventhough all teachers are amended to reach the purpose of teaching but spesifically professional competence is twice more practical than pedagogical competence. For instance, teachers must know the methods in pedagogical yet, in professional teachers are demanded to understand deeply the material, perceive the standard and basic competence of the subject matter, and to develop the subject creatively. On this point, as the English teachers they must ascertain the language with a deep comprehension as a mean of pointing out the lesson, but the researcher found that English language was still a rarity among English teachers. Darsyanto (2013) states the English teachers' professional competence for Islamic High School comprises to not only have a big understanding of language aspects in linguistic, discourse, sosiolinguistic and strategy but also master English in receptive and productive.

From example, those are indications that some teachers do not have good competence in classroom management which becomes one of the keys to classroom achievement. Futhermore, a teacher is asked to be a multitask person like a motivator for his or her students. In addition, questions rise up for what happens to this kind of teachers like?, what are the benefits of the training that they come to?,do they implement it?, and do they remember Teacher and Lecturer Consitution?

\section{REVIEW OF RELATED LITERATURE}

Sirojuddin (2011) pointed on The Correlation between Teachers' Professional Competence and Learning Effectivity in MTs. Annida Al-Islamy Rawa Bugel Bekasi Utara that it was in $41 \%$ of contribution between the both things. And other thing that made contribution were in $59 \%$.

Reinders in Cambridge University Press (2011) claimed that depending on the teacher's level of technological expertise, this could involve "being able to first, use a certain technology; second, being able to create materials and activities using that technology; third, being able to teach with technology" which means that a professional teachers could be claimed as they are if they have a comprehension

Handayani(2009) on Certified Professional Teachers in SMP Negeri 4 Tulakan Kabupaten Pacitan defined that teachers had the professional competence of certified educators in SMP Negeri 4 Tulakan Pacitan in developing professionalism through reflective action still needed to be improved where they found the teacher's participation in the activities of the forum MGMPs was still less than optimal. But it had a weakness in the wiriting teachers carry out scientific work and learning research.

It can be pointed out the relation between the past researches and my present research is commonly the pasts had spaces on the pedagogical and professional competence which was depicted on low rate on both rather than two other competencies, personal and social. Likewise, the pickup of technology is significantly crucial for teachers where almost schools 
are equipped by advanced technology such as LCD, computer or laptop in case that teachers are not blind of them. Therefore, the researcher means to know their capability of handling class furthermore in the view of technology.

1. Teacher Competence

Kunandar (2007:55) pointed out teacher competence is a set of skill to be owned by teachers in order to achieve the work clearly and effectively.Meanwhile Ramayulis outlines competence in education comprises personal, professional, pedagogic and social competence.

\section{English Teacher}

Oxford outlines English is the first, the language of English and secondly, the people of England. Webster explains a teacher is a person or thing that teaches something. Meanwhile, Murray potrays a teacher is a symbol of learning; a leader of learners and a miracle to education. Yet, Indonesian Dictionary mentions a teacher is the one who works for teaching. Accoriding Constitution No. 14 phase 12015 in Uno, teacher is a professionalism that aims to educating, teaching, leading, directing, training, assessing, and evaluating learner started from young learners to senior level.

\section{RESEARCH METHOD}

\section{The Technique of Data Analysis}

This qualitative study took method of data analysis that was suggested by Miles \& Huberman. According to Miles and Huberman (1992:18), there were two models in qualitative data analysis, flow model and interactive model. However, the writer chose to aplly the second model in this study. The steps that Miles \& Huberman take in conducting qualitative research data analysis shown in the following figure:

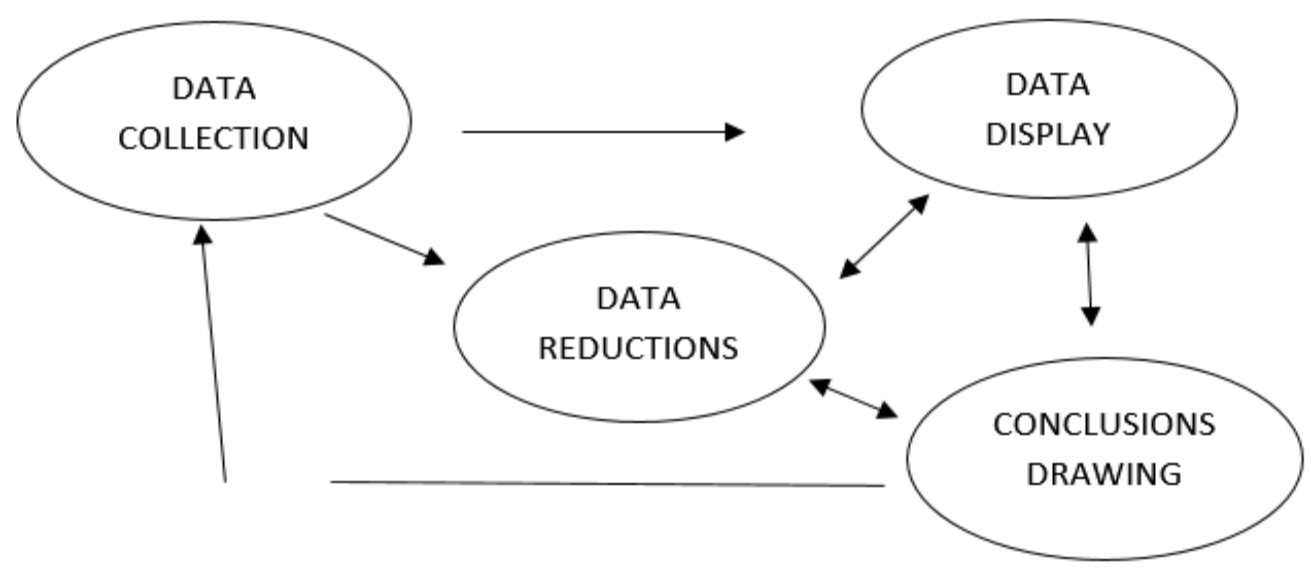

Those four types of data analysis could be explained as follows:

a. Data collection

As mentioned in the sentence above, the activity of data collection was a cyclical and 
interactive process. Thus, during the data collection the researcher circulated among these four steps continually in order to grasping all of the information needed in the next steps of data analysis. In the other words, it was the stage where the researcher tried to find out the unripe data that would be reduced, displayed, and concluded.

b. Data reduction

According to Miles and Huberman (1994:12), "Data reduction refers to process of selecting, focusing, simplifying, abstracting, and transforming the data that appear in the written-up fields notes or transcriptions". They further point out the data reduction or data condensation was varied in several ways, such as through selection, summary, or paraphrase and being subsume in larger pattern. After collecting the data, the researcher continued the study by selecting and simplifying the data so that there was no importrant locution included in the data.

c. Data display

After collecting and reducing the data, the researcher displayed the amassed data in organized and compressed. Information that would be lead to the conclusion. The forms of qualitative data displayed included types of matrices, graphs, charts, or networks. The function of these types of data display was to perform accessible, compac, and organized information on the data.

d. Conclusion drawing and verification

After the data displayed in a form of table, then the researcher was able to interpret it and reached conclusions and verifications. Derived from the data displayed in tables, the next step conducted by the writed was describing and interpreting the data in case that the conclusions and verifications of the of the speech act of the lecturers could be draw.

\section{FINDINGS AND DISCUSSIONS}

\section{A. Findings}

The researcher conducted an observation to attain the data by making a sign on the observation list which was consisted of totally reached, half-reached, and not reached in nine subcompetencies on which was seven of pedagogy and two of professional . next, the researcher had an interview with an English teacher to gain more accurate data. After having the data, the researcher would obtain it trough a descriptive.

\section{Pedagogical Competence}

a. Having a knowledge of students' characteristic

Table 4.1. Pedagogical Competence

\begin{tabular}{|l|l|l|c|}
\hline \multirow{2}{*}{$\begin{array}{c}\text { The English Teacher is able to identify the } \\
\text { characteristic of all students }\end{array}$} & Not met & Half met & Totally met \\
\cline { 3 - 4 } & & & YES \\
\hline
\end{tabular}


Nurul Azhar \& Mardiana, The English Teachers Competencies in English Foreign Language Learning . . .

It means that what the teacher did on the class was deeply monotonous, the teacher did not see the student need clearly. Furthermore, as a teacher, she/he might identify the style of learners which could make them comfortable as Jalal in The Teacher Certification in Indonesia(2009) stated that pedagogical competence should focus on the ability to understand the student learning style and characteristics in physical, social, cultural, emotional, moral and intellectual.

\begin{tabular}{|c|c|c|c|}
\hline $\begin{array}{c}\text { The English Teacher assures all students } \\
\text { have same chance to actively participate in } \\
\text { the learning process. }\end{array}$ & Not Met & Half met & Totally met \\
\cline { 2 - 4 } & & YES & \\
\hline
\end{tabular}

One depicted that students had same oppotunities to participate actively in the class was when the teacher made an ice breaking then all students tried to guess what the teacher wanted to convey. But after coming in to the lesson, the researcher found that it was not a total attention from the teacher to students when the learning took place. It was, maybe at ice breaking; all students tried to come up with the teachers but it was the reverse to the content. For example, when the teacher began to explain the kinds of announcement; oral and written announcement, the teacher seemed to look partially to students.

The English Teacher is able to manage the class in order to make students have equal chance despite the physical disorder

\begin{tabular}{|c|c|c|}
\hline Not Met & Half Met & Totally met \\
\hline & & YES \\
\hline
\end{tabular}

On the one hand, if we see this occurence, it is absolutely back to teacher who is right to control the class. But, after times of explanation, the teacher just looked innocent and never figured that out. Another example of students devastation was of students sleeping in the class and their back and forth for several times. The researcher thought that the possibility of that thing was because of the motonous teaching.

\begin{tabular}{|c|c|c|c|}
\hline $\begin{array}{c}\text { The English Teacher tries to know what } \\
\text { makes students turn over in the aim of not } \\
\text { impacting the other stundets. }\end{array}$ & Not Met & Half Met & Totally Met \\
\cline { 2 - 4 } & & YES & \\
\hline
\end{tabular}

When the teacher just made a motonous, it simply caused students to a devastation. For example, the students slept in the classroom or went back and forth, and other just tried to shout or mumble. As long as the researcher observed, there was no enough attempt of the teacher to calm the students; it was because of the small voice and uncapability of teacher to spread over in every single spot of the class room. But after times, the teacher appeared annoyed, and tried to figure out. At that time, she found two students who could not stop mumbling. Then, the teacher called them and she asked them "why you mumble"? one student answered "it is not me but he(pointing to his partner) does first". Afterwards, the 
teacher pleased them to have a seat again and acted out-of-box. Meaning, she tried to tell her past experience to the students till a ridicolous one such as her struggling, love and motivation that made her present position, teacher, and that was quite interesting and making the students laugh. Afterwards, the class was back to a calm, and ran well.

\begin{tabular}{|c|c|c|c|}
\hline $\begin{array}{c}\text { The English Teacher helps to } \\
\text { enchance the students' potential, and } \\
\text { figure out their negativity }\end{array}$ & Not Met & Half Met & Totally Met \\
\cline { 2 - 4 } & & YES & \\
\hline
\end{tabular}

On this point, it looks same as what happens to the previous point. On the one hand, the researcher concluded that the potentials meant to be where the aspect of language itself since they were in EFL classroom; they are speaking, writing, and reading. On the other hands, looking to what happened in the class was out of expectation that was based on same chance to students to have learning equally. It is mentioned again that only the front students gained much attention from the teacher. In spesific, if we just refer to the three aspects in the following; Speaking, the researcher found that there was no much attention to enhance the speaking ability.

b. Understanding the principle of an educated learning

The English teacher uses many techniques of learning to encourage the students to learn

\begin{tabular}{|c|c|c|}
\hline Not Met & Half Met & Totally Met \\
\hline YES & & \\
\hline
\end{tabular}

On this case, the figure of teacher as a motivator were crucially needed to make the transfer of knowledge went correctly. Yet, there was no enough attention from the teacher to this case. The only thing that the researcher caught to attract the students was HI HELLO call; when teacher said HI the students did HELLO and the reverse. But after a moment looking to material, the focus of some students was gone. On this finding, some informants ask for various learning activities because they commonly faced straightly motonous as conducted by two different teachers, this might be games. RR "Klo bu A bagaimana biasa caranya motivasi, seringij namotivasiko kh? Student: jarang, kalo pak I bukanji motivasi cuman ada permainan-permainannya, interviewer: itumi, student: yang langsungki nda sengaja langsung dihafal itu kosa kata, interviewer: oo yayayyaya, kalo bu A nda da di'? student: garing, interviewer: garing" while SA "interviewer: apa biasanya game-gamenya pak. I? Student: gamenya itu kayak anu bagaimana di' gamenya kayak siswa berdiri menghafal begini kalo misalny a sambung kata, interviewer: sambung kata? Owwh iyyo mengertima, student: sambung kata kalo disurubki hafal, dia bisa kayak dia bisa merubah lagu jadi kosa kata apa contohnya kayak balonku ada lima dia ubah jadi kosa kata, interviewver: oo begitu menterjemahkan di'? student: dia ubah kosa kata jadi bahasa inggris begini, interviewer: jadi napeccai itu kata, misalnya balonku=my balloon,student: bukan kayak, kosa kata lain dia bikin lagu tapi mirip 
Nurul Azhar \& Mardiana, The English Teachers Competencies in English Foreign Language Learning ...

dengan balonku ada lima, interviewer: oo mirip nadanyaji, student: eeaaa, interviewer: tapi lagunya bedai, ooo yayayaaya, bagus bagus".

From some conversation with students above, it significantly potrayed that the basic competence of English language was a vital role for students to rise up, moreover after an interview with a teacher, it clearly strenghtened why some students did not feel motivated in the classroom besides the various techniques.

c. Having a knowledge of curriculum development

\begin{tabular}{|c|c|c|c|}
\hline \multirow{2}{*}{$\begin{array}{l}\text { The English teacher makes a lesson plan as } \\
\text { set in syllabus to explain the current material } \\
\text { that can make the students achieve the basic } \\
\text { competence }\end{array}$} & Not Met & Half Met & Totally met \\
\hline & & & YES \\
\hline
\end{tabular}

On this term, the researcher assumed that the teacher had knowledge of the current curriculum. In fact, there are two types of curriculum used; K-13 and KTSP, and what has been used by teachers including the English teachers in that school is KTSP curriculum. Furthermore, it was a long existing curriculum after a moment transfer to K-13 several months ago, but they decided to back in style of KTSP. Moreover the lesson plan set by the English teacher during the researcher observation was on KTSP procedure.

The English teacher follows the order of learning by looking the goal of the learning

\begin{tabular}{|l|c|l|} 
Not Met & Half Met & Totally Met \\
\hline & YES & \\
\hline
\end{tabular}

The learning goals according to the lesson plan are at the end of the class the sudents can explain the announcement in front of the class orally and the students can retell the announcement has been described in the class room. Explaining means to present other people by own words without seeing the object. But on the other hands, what the researcher found on the field was out of expectation. If it refers to individual, it can cover the two of the learning goals because only some certain people could do that while on the whole learners some people could not do that. In addition, people came forward not to explain but just retell the text by reading it. Thus, it could not be pointed that the students could explain the material. In spesific, some of people regarded to a good comprehension just could explain by own words with Indonesian language meanwhile it was pushed to use English.

d. Learning activities educated

\begin{tabular}{|c|c|c|c|}
\hline \multirow{2}{*}{$\begin{array}{c}\text { The English teacher conducts the learning } \\
\text { activity based on the plan compeletely }\end{array}$} & Not Met & Half Met & Totally Met \\
\cline { 2 - 4 } & & YES & \\
\hline
\end{tabular}

On this point the researcher combined between the observation of the class activity and the lesson plan. At that time, the teacher entered the room and waited the rests out after 
the previous table of sport. while waiting, the teacher tried to communicate with the students in by asking the where the rests were. In short, after all came, the teacher began to start the class by allowing the leader to command the pray before learning activities and checked the attendance list.

Next, she explained the goal of the learning followed by the competencies that would be gained by students. Afterwards, the teacher explained the objective of the learning. Furthermore, it came to the core of learning activities; the teacher gave a stimulus for measuring how far sthe students would settle with the material. Shortly, the teacher came to real material by discussing and asking the students where they usually saw boarding or heard announcement. Furthermore, after a moment discussion, the teacher present the example of material by displaying it by LCD projector and students wrote the material. Yet, there was no confirmation activity, assignment as set in the lesson plan either a class task or a homework.

\begin{tabular}{|l|l|l|c|} 
The English teacher arranges the class with no & Not Met & Half Met & Totally Met \\
\cline { 4 - 5 } \begin{tabular}{c} 
anyother activities dominant on her class. \\
\cline { 4 - 5 }
\end{tabular} & & & YES
\end{tabular}

During the observation, the researcher potrayed that there was no other activities for example typing mobile phone or leaving the class. She just focused on the current activity. But on the other hand after an interview with a student, researcher found an opposite finding (see appendixes of interview with student 2) "interviewer: nda uletki? Bagaimana kayak caranya menjelaskan? Bagusji? Student: bagaimana di?(confusing), nda terlalu anuki, nda terlalu mengajarki, sibukji jalan-jalan, interviewer: masa?? sering keluar begitu?, another time the $Y$ cut and said: masa satu kali ji orang mengajar ulangan mki, student: iyye kak, satu pembahasan ulangan lagi, interviewer: tapi massu'ku yang tadi, itu tadi sibuk jalang-jalang bagaimana itu? Sering keluar begitu? Student: tidak kak, mondar-mandir terus, tidak jelas apa yang diajarkan". As we can see that this teacher named with initial A sometimes do another activity out of learning.

The English teacher uses the other media to support the learning process like TIK to encourage the leaners to study.

\begin{tabular}{|l|l|c|}
\hline Not Met & Half Met & Totally Met \\
\hline & & YES \\
\hline
\end{tabular}

Commonly, schools have their own English guide book to distribute to students as their tool for study or extention preparation of examination. Nevertheless, when the researcher was in the class, it felt peculiar because of the absence of book for students. Yet after times, the teacher set up a laptop with its LCD to display the material in front of the learners. Thus, the activity of learning like writing and reading the content ran well. We can see the confrontation among students in the use of LCD projector in the class (see appendixes of interview with student 1) 'interviewer: tapi mulia' selama ini pak A sama bu I 
Nurul Azhar \& Mardiana, The English Teachers Competencies in English Foreign Language Learning . . .

bawakah buku, buku sendiri? Kalo pak. A jarang, nahaf, nakuasaimi materi, kalo ibu A nasuruki belli buku, interviewer: tapi itu kadang pake LCD, bagusji kh kira-kira kalo pake LCD?, student: nda, mending langsung ditulis, interviewer: ooo mending langsung ditulis?, student: iyye" which means that the teacher I used to have her own book for the classroom learning. In addition, she used to use technological tool to improve the learning condition. But we can see that times when they used book were followed LCD which means that the teacher had additional material to give meanwhile according to this student, the another teacher, I mastered the lesson to give in case of a rarity of bringing books.

e. The Progressing of learners potential

\begin{tabular}{|c|c|c|c|}
\hline $\begin{array}{c}\text { The English teacher plans and conducts } \\
\text { learning activities which can support learners to } \\
\text { study as their mode and capability }\end{array}$ & Not Met & Half Met & Totally Met \\
\cline { 3 - 4 } & & YES & \\
\hline
\end{tabular}

On one point, it was probably caused by capability of the teacher to handle the class which was referred to learning style of the learners, then they felt unmotivated to follow the class. For example, when that teacher was quite unable to control the situation. Furthermore, at that time it might be a game of announcement to boost the students will to feel enyoable to learn English. In addition, the devastating learners just kept doing their activities without any correctness from the teacher. For instance, the backline teachers who seemed difficult to absorb the material did not receive any fixation from the teacher. It is proved by the results of interview with some students (see appendixes of interview with student $1, \mathbf{R R}$ ) "tapi dibandingkan sama anu eee Pak I sama Bu A, kalo pak I sama.. pernabka juga dapat Bu $\mathrm{R}$ debhb itu keren, itu dua iyya, bu G sama Pak I baguski, apa di'? Pak I tassediki'ji memang materi nakasiki tapi yang penting dipahami begitu juga bu $\mathrm{R}$ terus ada waktunya main ada waktunya belajar terus tegaski juga itu berdua, interviewer: eee kalo anu disejajarkan sama Bu A, student: Bu A masih kurang, interviewer: masib kurang, artinya segi anunya penjelasannya, student: segi penjelasannya, prononsiasennya juga bu $A$ belum bagus, interviewer: jelle mudengar?, student: iyya jelle'ki".

\begin{tabular}{|c|c|c|c|}
\hline $\begin{array}{c}\text { The English teacher focuses on students' } \\
\text { interraction and push them to understand and } \\
\text { use the information delivered. }\end{array}$ & Not Met & Half Met & Totally Met \\
\cline { 2 - 4 } & & YES & \\
\hline
\end{tabular}

One of ways to make students absorb the material was by speech of the teacher and it worked for some students besides questionning. On the contrary, there was no further work for students on how they could input the material, moreover, the researcher saw that the learning style of students was different; some students were pro active proved by messing up with others but not directed to learning. Therefore, to handle this, it needed some approach to make students go for the material. 
As mentioned ahead, the teacher A did not concern on how students could make interraction in learning like group or mate task but it is distinct to what teacher I focused on like chain words game as mentioned in advance that make students connected. Besides, he revealed another type of learning which was student-based learning as seen in an interview (see appendixes of interview with student 4 SA) "student: kalo pak I dia berusaba kayak nakasi buku disurub cari apa kata kerjanya, apa kata sifatnya, kita sudah tau kayak pronounnya begini begini, ini yang disuruh cari begini”.

f. Communication with the learners

\begin{tabular}{|c|c|c|c|}
\hline $\begin{array}{c}\text { The English teacher ask question to know the } \\
\text { understanding of students like an open } \\
\text { question that makes the students answer by } \\
\text { their own idea. }\end{array}$ & Not Met & Half Met & Totally Met \\
\cline { 2 - 4 } $\begin{array}{c}\text { then } \\
\text { Ty }\end{array}$ & & YES & \\
\hline
\end{tabular}

The researcher found that how the teacher did communication with the students was at the beginning of the class when the teacher tried to measure the students pre-knowledge of the material. Besides, the teacher tried to attract the students by telling the past experience when at school, and it worked. In addition to assure the students understanding, the teacher sometimes ask the students by saying "understand" then the students said that as well, meaning to show their understanding. (see appendixes of interview with student 4 SA) "Interviewer: kerja kelompok, student: kerja kelompok saja anu biasa kalo kita anggap benar dia anggap salah, interviewer: kenapai? Apa tadi mubilang? Student: kelompok? Sudah menurutta benar dia menurutnya salah, interviewer: owwh, oo begitu memang". On this point, the teacher initial A used to make a connection through interactive discussion to students.

\begin{tabular}{|c|c|c|c|}
\hline $\begin{array}{c}\text { The English teacher present the learning } \\
\text { activities that is able to encourage the learners } \\
\text { teamwork. }\end{array}$ & Not Met & Half Met & Totally Met \\
\cline { 2 - 4 } $\begin{array}{c}\text { team } \\
\text { YES }\end{array}$ & & \\
\hline
\end{tabular}

During the observation, the researcher did not find any activities that could involve students interraction. Among the English teachers, teacher A and I, the students preferred the teacher I to A because of teacher I's way of presenting the lesson. For example, this teacher used to making a game such as singing and chain words as found in an interview with a student (see appendixes of interview with student 4 SA) "Student: gamenya itu kayak anu bagaimana di' gamenya kayak siswa berdiri menghafal begini kalo misalnya sambung kata, interviewer: sambung kata? Owwh iyyo mengertima, student: sambung kata kalo disurubki hafal, dia bisa kayak dia bisa merubah lagu jadi kosa kata apa contohnya kayak balonku ada lima dia ubah jadi kosa kata, interviewer: oo begitu menterjemabkan di? student: dia ubah kosa kata jadi bahasa inggris begini, interviewer: jadi napeccai itu kata, misalnya balonku=my balloon,student: bukan kayak, kosa kata lain dia bikin lagu tapi mirip dengan balonku ada lima, interviewer: oo mirip nadanyaji, student: eeaaa". 
The English teacher attentively responds the answer of learners with relevant and compelete answer to erase the students confusion.

\begin{tabular}{|c|c|c|}
\hline Not Met & Half Met & Totally Met \\
\hline & & YES \\
\hline
\end{tabular}

On this occurence, the researcher found that the what the teacher did was very helping for the students. for example, when the teacher tried to stimulate the learner comprehension about the material by asking them the contents of announcement then they answer them correnctly and the reflection of a teacher was by writing their answer on the whiteboard; the contents of an announcement were title, date and time, goal, and event provider. Another case was when the teacher clarified what an announcement contains, but the students look confused. After minutes, the teacher mentioned that was event, then students showed their understanding. (see appendixes of interview with student 3) "sering ada siswa bertanya' kah? Student: seringii ada kak? Interviewer: sering...! tentang pelajaran? Student: e em, interviewer: najawabji, student: iyye najawabji, interviewer: bagusji nacaranya menjawab? Student: bagusji kak.". It explains that all teacher answered the question attentively well.

\section{g. Assesment and Evaluation}

\begin{tabular}{|c|c|c|c|}
\hline $\begin{array}{c}\text { The English teacher utilizes critics from } \\
\text { students to upgrade the upcoming learning, be } \\
\text { able to prove through note, learning journal, } \\
\text { lesson plan, and additional materials. }\end{array}$ & Not Met & Half Met & Totally Met \\
\cline { 2 - 4 } & & & YES \\
\hline
\end{tabular}

As long as the researcher observed, he found that the teachers covered this point which was proved by the material, lesson plan and book. It is supported by the interviews with students.(see appendixes of interview with student 3) "student: kalo di kelasku pak I nasurubki kerja tugas di LKS, sudah LKS nasuruki menghafal, ada lagi tugas Quipper biasa da, interviewer: jadi banyakji mudapa' di' banyakji mupahami baru pulang, hmbmbmbm(laughing), student: karena da lagi di Quipper kak, Quipper saja 50 nomor, interviewer: owwh yayayaaya, tapi bagusji kirakira kalo ada tugas di'? student: bagus, daripada malas-malaski toh tidur tidur" and (see appendixes of interview with student 4) "Student: kalo pak I, buku dia biking, interviewer: ooow dia bikin sendiri buku? Kalo bu $A$ adaji bukunya?student: tapi belum kita tau apa anunya, klo pak. A dia kasi liat apa anunya, edisinya, dia kasi tau bagaimana anunya, sudah itu kita dijelaskan, sudah itu kita mengerti, interviewer: ooo pak I bikin buku? Student: dia mengoleksi buku, interviewer: mengoleksi buku di? Bikin buku sendiri atau koleksi buku, student: mengoleksi buku sama buku sendiri". From the two information, it can be concluded the teachers have deep preparation for their learning tools, its official book, self-made book, technology use. Specially, in technology use, the researcher caught the teacher use Quipper School as a medium for displaying additional material, assignment and its result. 


\section{Professional Competence}

a. The English teacher masters the structure and concept that supports the lesson.

\begin{tabular}{|l|l|l|c|}
\hline \multirow{2}{*}{$\begin{array}{l}\text { The English teacher attaches a clear and } \\
\text { uptodate information in the lesson plan. }\end{array}$} & Not Met & Half Met & Totally Met \\
\cline { 3 - 4 } & & & YES \\
\hline
\end{tabular}

What the researcher found on the lesson plan was clear information to do. On the other hands, the activities were not in target because the set activities were to tell and to explain, meanwhile, it was out of context.

The English teacher sets the material, planning and activities to support the students understand the content.

\begin{tabular}{|l|c|c|}
\hline Not Met & Half Met & Totally Met \\
\hline & & YES \\
\hline
\end{tabular}

The researcher found that the set of materias were totally prepared. But the activities were into trouble. In other words, one teacher only set a planning for activities on lesson plan (RPP) and did as she set but it was only activities, the students boredom rose up without any wayout to a fun learning.

b. Developing the professionalism through a reflective action

\begin{tabular}{|c|c|c|c|}
\hline $\begin{array}{c}\text { The English teacher conducts research, develop } \\
\text { an innovation, and follow a scientific forum such } \\
\text { as seminar and conference. }\end{array}$ & Not Met & Half Met & Totally Met \\
\cline { 3 - 4 } & & & YES \\
\hline
\end{tabular}

(See appendixes of Interview with a teacher) "Interviewer: begini bu, guru semestinya melakukan peningkatan keprofesionalan berkelanjutan, tindakan apa yang ibu lakukan dalam melakukan peningkatan keprofesionalan berkelanjutan? Apakah ibu tergabung dalam suatu forum guru, atau pernah mengikuti seminar atau workshop? Informan: kalau mengikuti forum-forum ya biasa.. kalau ikut diklat secara ini eee apa namanya? secara terprogram begitu ada juga namanya MGMP bidang studi mata pelajaran dan saya kira untuk meningkatkan profesionalisme guru, saya kira bukan hanya sekedar mengikuti diklat-diklat tapi harus membangun dirinya sendiri atau apa namanya? belajar melatih dirinya sendiri agar dia bisa lebih baik." on this interview, it is clearly understood that the teacher always pay attention to the professionalism which is main part of teaching and amid the interview the researcher asked about the interraction between teachers regard with professionalism enhancement and she showed positivity (see appendixes of interview with a teacher) "Interviewer: misalnya apakah ibu pernah dalam ruang lingkup Madani terbubung dengan guru Bahasa Inggris lain kemudian saling sharing tentang peningkatan keprofesionalan berkelanjutan itu?Informan: Ya”. 


\begin{tabular}{|c|c|c|c|}
\hline \multirow{2}{*}{$\begin{array}{c}\text { The English teacher uses IT in } \\
\text { communication and conduction of PKB. }\end{array}$} & Not Met & Half Met & Totally Met \\
\cline { 2 - 4 } & & & YES \\
\hline
\end{tabular}

On this point, the researcher found that the teacher was in the deep use of technology, its laptop and LCD projector for additional material display. On a chance, the researcher found a new thing that he never found in advance as long as his observation to teacher class, Quipper School. This is a medium for students collection task, the upcoming material information, and examination result. In an unstructure interview, the researcher asked the teacher of its whoever access, then, she said no for students university but only for school with its compelete data to $\log$ in. Furthermore, it is supported by an interview with the teacher and student (see appendixes of interview with a teacher) "Interviewer: begini bu, peran teknologoi dalam pembelajaran, apakah ibu menggunakan teknologi?Informan: Banyak! Banyak sekali perannya anunya. Kalau menurut saya, peran teknologi itu sangat penting penting penting sekali. Dalam pembelajaran secara online saja itu ee misalny a sekarang saya sudah menggunakan secara online itu ada namanya ada namanya ee link yang bisa namanya Quipper School, itu sudah saya linkan anak-anak kesitu dengan membuat kelas Bahasa Inggris secara online. Jadi dalam proses pembelajaran itu saya bisa lakukan dengan online terutama dalam penugasan-penugasan. Interviewer: obh iyya, jadi misalnya selain penugasan apakah bisa tatap muka secara online?Informan: iyya, tapi kekurangannya karena kekurangannya mungkin dari fasilitias kita yang untuk apa namanya penyediaan apa namanya eee akses internet kita di sekolah kitakan belum ini jadi itu kekurangannya belum bisa terpenubi jadi untuk memenubi itu paling penugasan-penugasan di luar kelas ee misalnya PR itu secara online saya berikan atau kalau misalkan saya mau terapkan di kelas sya minta anak-anak untuk bawa laptop sendiri, modem sendiri untuk bisa akses internet secara langsung di kelas. It is clear that all teacher use the technology for learning in the reason of its facility and speedy.

\section{DISCUSSION}

Based on the findings, the existence of pedagogical and professional competence could be put in average based on the observation and interviews results. In spesific, it puts big demands on the following, Firstly, Character and need of students. The teacher on this side less put attention on the equality of learning chance, necessary identification, and caring. Secondly, attracting students to focus. On this case, there were no enough attention proved students keept turning over by the class. Thirdly, teaching and learning emphasized. This focused on how the teacher acted into the class and how the students reacted toward it. Meaning, the teacher only presented a motonous style of teaching and not found the activities that could involve the students. Therefore, those three points must be the focus by the teacher as Liakoupoulou (2011) on the Professional Competence of Teachers: Which Qualities, Attitudes, Skills, and Knowledge contribute to a teachers' effectiveness? Pointed 
out that good teachers were most teachers seem to associate their effectiveness at work with both personal traits and didactic and pedagogical skills as well as pedagogical knowledge. These particular findings contributed to a systematic and analytical description of the content of professional knowledge require for the successful performance of a teacher's pedagogical and didactic work.

On one point, the students as well imititated the English of teachers which could make their enthusiasm; if their English was not good the students were low on courage to study. Meaning, fluency and use of English holds a vital role as Neta and Klu (2013) on Teachers' Professional Competence and Second Language Education ins South Africa concluded, firstly, by emphasizing that teacher training programs have to be fore-grounded in professional knowledge that is congruent with appropriate theoritical frames underpinning English as a medium of instruction, secondly, by acknowledging the pervasiveness of language across discipline which embeds fact that teacher is a language teacher and as such, teachers need to be explicitly apprenticed in professional knowledge for the facilitation of new forms of practice as identities for themselves and their learners.

Likewise, the technology in classroom must be in significantly proper use whether by technical and material which was demanded by the learners. It was because of the learners technology rate was high. Reinders in Cambridge University Press (2011) explained the professional teachers are claimed as they are if they have a comprehension of technology amid the technological own by their students which stands in first, use a certain technology, second, being able to create materials and activities usint that technology, third, being able to teach with technology.

\section{CONCLUSION}

Based on the finding and discussion the researcher concluded as follows, The pedagogical competence between two teachers was in different level. In this competence, the main factor of a succeeded learning was on how they attracted the students by giving games. Most of students rejoiced with various learning activities eventhough it was a task rather than wasting time. On one side, they needed materials which were deeply correlated with their daily lifes in order to prepare their English. In professional competence, the teachers were placed in the safe phase due to the result of interview and observation. On one side, the teachers should keep improving on this because this competence was the impelementation of all competencies, furthermore, teachers should place them equally as students because of the rate of informational progress.

\section{SUGGESTION}

The researcher suggest on the following element, firstly, students of university regard with this competencies should keep up by always enriching their world-wide sights that can 
Nurul Azhar \& Mardiana, The English Teachers Competencies in English Foreign Language Learning . .

reside them to the need in the future education,secodnly, for teachers, they should be much more competent on language teaching by having more improvisation, searching for more resoruces explaining the competence and the performance in language teaching and finding out more ice breakings for students attraction, thirdly, for another researcher, in the term of quality of education, this like research must be conducted in order to know the moment teacher competencies, furthermore, there must be the rest competencies put, social and personal competence.

\section{BIBLIOGRAPHY}

Arifin, H.M. Kapita Selekta Pendidikan Islam dan Umum. Jakarta: Bumi Aksara. 1991.

Arikunto, S.Procedure Penelitian: suatu pendekatan praktik(Cet.15). Jakarta:Rineka Cipta. 2013.

Arif, Arianti, Irma. Analisis Kompetensi Guru. A Thesis of Universitas Hasanuddin, 2013.

Atherton, James. February 24, 2015. Competence, Proficiency and Beyond. (Online) Retrieved from http://www.doceo.co.uk/background/expertise.html (July 31, 2015)

Cuhendi, Enang. Kualifikasi Akademik dan Standar Kompetensi Guru. Retrieved on August 13, 2015 from: enangcuhendi.blogspot.com/2011/12kualifikasi-akademik-danstandar.html

Darsyanto. Standar Kompetensi Dan Pnilaian Kerja Guru Profesional (Cet. 1). Yogyakarta: Gava Media. 2013.

Gay, R., L dkk. Educational Research: Competencies for Analysis and Applications. Columbus: Pearson Education. 2006.

Hackitt, Judith. ------ What is Competence? (Online) Retrieved from http://www.hse.gov.uk/competence/what-is-competence.htm (July 31, 2015).

Handayani, T. The Professional Competence of Certified Teachers in SMP Negeri 4 Tulakan Kabupaten Pacitan. A Thesis of Universitas Muhamaddiyah Surakarta. 2013.

Jalal, Fasli \& others. Teacher Certification in Indonesia: A Strategy for Teacher Quality Improvement. Ministry of National Education. 2009.

KBBI. January 2015. Definisi Guru. (Online) Retrieved from http://kbbi.web.id/guru. (July 28, 2015).

Kunandar. Guru Profesional Implementasi KTSP dan Persiapan Menghadapi Sertifikasi Guru. Jakarta: Rajagrafindo Persada. 2007.

Liakopoulou, M. The Professional Competence of Teachers: Which qualities, attitudes, skills and knowledge contribute to a teacher's effectiveness? A Thesis of Aristotle University of Thessaloniki, 2011.

Mulyasa, E. Standar Kompetensi dan Sertifikasi Guru (Cet. 6). Bandung: PT. Remaja Rosdakarya. 2012.

Murray, Phyllis C. February 13, 2009. What is a teacher?. (Online) Available from: http:/ /www.edwize.org/what-is-a-teacher. (July 28, 2015) 
Mustafah, J. Peningkatan Kompetensi Guru: Melalui Pelatiban dan Sumber Belajar Teori dan Praktik. Jakarta: Kencana. 2011.

Nesrin, A. English LanguageTeachers' use of, competence in and professional development needs for classroom activities.Akdeniz Language Study Conference. 2012.

Neeta, C., Nande \& Klu, K., Ernest. Teacher Professional Knowledge Competence and Second Language Education in South Africe. Retrieved on August 2, 2015 from: www.sciencedirect.com. 2013.

Oxford. Learner's Pocket Dictionary. China: Oxford University Press. 2011.

Penn, S \& Edwards. The Competencies of an English Teacher: Beginning Student Teachers' Perceptions. A Thesis of Griffith University, 2010.

Ramayulis. Profesi dan Etika Keguruan. Jakarta: Kalam Mulia. 2013.

Richards, C., J. Competence and Performance in Language Teaching. New York: Cambridge University Press. 2011.

Samad, A. June 3, 2012. Pengertian Profesi Menurut Para Abli. (Online) Retrieved from http://samad717.blogspot.com/2012/06/profesi-menurut-para-ahli.html. (July 31, 2015).

Santoso, B. September 25, 2012. (Online) Retrieved from: https://inisantoso.wordpress.com/2012/09/25/definisi-profesional. (July 29, 2015).

Sirajuddin, A. The Correlation between Teachers' Professional Competence and the Learning Effectivity in MTs. Annida Al-Islamy Rawa Bugel Bekasi Utara.A Thesis of Universitas Islam Negeri Syarif Hidayatullah Jakarta. 2011.

Syahruddin \& Ernawati, Andi. The Role of Teachers' Professional Competence in Implementing School Based Management: Study Analisys at Secondary School in Pare-Pare City of South Sulawesi Province-Indonesia. A Thesis of Universiti Teknologi Indonesia, 2013.

Uno, H, B. Profesi Kependidikan. Jakarta: Bumi Aksara. 2007.

UU RI No. 14 Th. 2005. Guru dan Dosen. Jakarta: Sinar Grafika. 2005.

Webter, Merriam. ----- Teacher Definition. (Online) Retrieved from: http:// www.i.word.com/idictionary/teacher. (July 28, 2015).

Wibowo, Eko M. ------ Perbedaan pengertian Profesi, Profesional, Profesionalitas,Profesionalisasi, dan Profesionalisme. (Online) Retrieved from http://mekowpunya.blogspot.com/2014/06/ perbedaan-pengertian-profesi.html. (July 29, 2015). 